\title{
A Study of the Physiological Response of Pichia pastoris Growing in a Continuous Culture to an Induced Stress Situation
}

\author{
Petr Hyka ${ }^{\mathrm{a}}$, Leona Paulováa ${ }^{\star}$, Manuel Egger ${ }^{\mathrm{b}}$, and Karel Melzoch ${ }^{\mathrm{a}}$
}

\begin{abstract}
During our work, flow cytometry was used for a study of the influence of cultivation conditions on a physiological state, mainly on the viability and vitality of the recombinant Pichia pastoris strain producing $\beta$-galactosidase. The fluorescent dyes propidium iodide and bis-(1,3-dibutylbarburic acid) trimethine oxonol were used for the determination of the structural integrity and the membrane potential of Pichia pastoris cells, respectively. First the staining procedures were optimised and adapted for the Pichia pastoris yeast cells and later applied in a lab-scale continuous cultivation. Stained samples were analysed with the flow cytometer PAS III Partec or the epifluorescence microscope Nikon Eclipse E400. The following conditions were found to be optimum for the staining of Pichia pastoris cells: $57 \mu \mathrm{g} / \mathrm{ml}$ propidium iodide in the sample, $5 \mathrm{~min}$ incubation time; $2 \mu \mathrm{g} / \mathrm{ml} \mathrm{bis-(1,3-di-}$ butylbarburic acid) trimethine oxonol in the sample, 20 min incubation time. The optimised staining methods were employed in a study of stress-induced physiological response to change of substrate from glycerol to methanol in a glycerol steady state growing culture of Pichia pastoris yeast. During the first $5 \mathrm{~h}$ of the transitional state an accumulation of methanol in the culture broth was accompanied by a decreasing concentration of biomass and an increasing amount of cells stained with propidium iodide and bis-(1,3-dibutylbarburic acid) trimethine oxonol. After the adaptation phase the amount of cells stained with propidium iodide and bis-(1,3-dibutylbarburic acid) trimethine oxonol reached steady levels of $2 \%$ and $5 \%$, respectively.
\end{abstract}

Keywords: Continuous culture $\cdot$ Flow cytometry $\cdot$ Physiology $\cdot$ Pichia pastoris

\section{Introduction}

Biotechnological processes are non-linear systems that are affected by both the complex interactions of the cell population with its microenvironment and other technical and biological factors. Although numerous process monitoring and control tools have been developed in recent years, most of these only measure the average values and 'ignore' the single-cell heterogeneities in the

\footnotetext{
${ }^{\star}$ Correspondence: Dr. L. Paulováa

Tel.: + 420224355022

Fax: +420 220445051

E-Mail: leona.paulova@vscht.cz

alnstitute of Chemical Technology Prague

Department of Fermentation Chemistry and

Bioengineering

Technická 5

16628 Prague 6, Czech Republic

bUniversity of Applied Science Wädenswil

Grüental

Postfach 335

$\mathrm{CH}-8820$ Wädenswil, Switzerland
}

bioreactor that could significantly influence the productivity and product quality [1][2]. Direct methods of analysis of microorganisms on a single-cell level enable the quick measurement of the physiological attributes of cells, provide a better understanding of the interactions between the cells and their microenvironment and can serve as a basis of information for the development of new control algorithms based on a detailed knowledge of a physiological state of the cell culture. Several methods exist for the study of physiological states on a single cell level [3]. One of them is flow cytometry which is a promising method for the study of both the physiological attributes of individual cells and their distribution in cell cultures in a relatively short time of only several minutes [4].

One of the most important pieces of information in biotechnological processes is information about the viability of the cell culture. Viability is always connected to vitality, which is understood as an activity or a metabolic performance of a microorganism and can also be seen as a function of the total cell viability and the physiological state of the viable cell population [5]. When a cell is stressed energetically, firstly the ac- tive transport system ceases, then the cytoplasmic membrane depolarises and finally permeabilisation indicating the cell death occurs [6]. According to the above-mentioned facts, changes in membrane potential and membrane permeability can be considered as one of the first indicators of the stress situation resulting in a cell death.

A wide range of fluorescent probes is available to determine the above-mentioned physiological parameters of yeasts. Contrary to traditional methods, physiological probes for the real-time monitoring of the viability of cells do not allow to directly monitor cell division, but only the detection of the presence of some active functions such as metabolic activity, intracellular $\mathrm{pH}$, enzyme activities and membrane integrity. The fact that complex cellular functions other than growth can be detected opens the possibility for distinguishing different states that exist between the classical definition of alive and dead cells such as stressed, injured or otherwise so-called viable but non-culturable cells [1][6][7].

Although the physiology and metabolism of the yeast strains has been extensively studied, many questions remain unanswered in the field of recombinant 
yeast cultivation and induced production of recombinant protein [8]. It was demonstrated by Diaz-Ricci et al. [9] that metabolic kinetics are significantly different between the host carrying the cloning vector and the host without the vector i.e. the wild strain. Most papers published focus on genetic factors such as the codon usage of the expressed gene [10], the gene copy number [11][12], efficient transcription by using strong promoters, translation signals [13], translocation determined by the secretion signal peptide [14][15], processing and folding in the endoplasmatic reticulum and Golgi apparatus [16], and, finally, secretion out of a cell [17] as well as the protein turnover by proteolysis [18]. Since all these factors are independent of each other it is not trivial to optimise such a system dependent on several variables [19]. Although several studies on the physiology of recombinant yeast were provided [20][21], there is still a demand for systematic studies on the coherent relationship between the heterologous protein expression and the host cellular metabolism.

\section{Material and Methods}

\section{Strain}

All the experiments were carried out with the recombinant Pichia pastoris strain GS115/lacZ/Mut+/His+ from Invitrogen which contains the LacZ gene of E.coli to express intracellularly $\beta$-galactosidase.

\section{Inoculum}

The inoculum for the cultivation in the bioreactor was prepared in two steps. The seed-cultures were grown on complex BMGY medium in shake flasks with baffles at $28{ }^{\circ} \mathrm{C}$ and $150 \mathrm{rpm}$. One vial (ca. $\left.1.5 \mathrm{ml}\right)$ of frozen glycerol stock culture was transferred into $50 \mathrm{ml}$ medium and grown for $24 \mathrm{~h}$. Then the entire volume of this preculture was transferred to the shake flask with baffles containing a $100 \mathrm{ml}$ medium and grown for $24 \mathrm{~h}$.

\section{Media}

The buffered glycerol-complex medium (BMGY; Invitrogen, [22]) for the precultures contained per litre: glycerol $10 \mathrm{~g}$, yeast extract $10 \mathrm{~g}$, peptone $20 \mathrm{~g}, 100 \mathrm{mM}$ potassium phosphate buffer ( $\mathrm{pH} 6.0$ ), yeast nitrogen base without amino acids $13.4 \mathrm{~g}$, and biotin $0.0004 \mathrm{~g}$.

For cultivations basal salts medium by Hellwig [23] with trace solution PTM1 by Invitrogen [22] was chosen. The mineral medium without glycerol, the EDTA solution, the trace elements solution, biotin and histidine was autoclaved at $121{ }^{\circ} \mathrm{C}$ for 20 min. The glycerol stock solution $50 \%$ (w/ v) was autoclaved separately. The trace elements PTM1, EDTA, biotin and histidine were prepared as four separate stock solutions: PTM1, 3\% EDTA, $0.02 \%$ biotin and $0.4 \%$ histidine. They were sterilised by filtration (Invitrogen). The completed medium was transferred into the reactor and the $\mathrm{pH}$ was adjusted to 6.0 with $\mathrm{NH}_{3}$ aq $25 \%$.

The mineral medium contained per litre: glycerol $20 \mathrm{~g}, \mathrm{CaSO}_{4} \cdot 2 \mathrm{H}_{2} \mathrm{O} 0.17 \mathrm{~g}, \mathrm{~K}_{2} \mathrm{SO}_{4}$ $2.86 \mathrm{~g}, \mathrm{MgSO}_{4} \cdot 7 \mathrm{H}_{2} \mathrm{O} 2.32 \mathrm{~g}, \mathrm{NaCl} 0.22 \mathrm{~g}$, $85 \% \mathrm{H}_{3} \mathrm{PO}_{4} 7.23 \mathrm{~g}(4.25 \mathrm{ml}), \mathrm{KOH} 0.64 \mathrm{~g}$, PPG $0.1 \mathrm{ml}, 3 \%$ EDTA $20 \mathrm{ml}, 0.4 \%$ histidine $10 \mathrm{ml}, 0.02 \%$ biotin $4.35 \mathrm{ml}$ and PTM1 $4.35 \mathrm{ml}$.

The PTM1 stock solution contained per litre: $69 \% \mathrm{H}_{2} \mathrm{SO}_{4} 5.0 \mathrm{ml}, \mathrm{CuSO}_{4} 3.84 \mathrm{~g}$, NaI $0.08 \mathrm{~g}, \mathrm{MnSO}_{4} \cdot \mathrm{H}_{2} \mathrm{O} 3.0 \mathrm{~g}, \mathrm{Na}_{2} \mathrm{MoO}_{4} \cdot 2 \mathrm{H}_{2} \mathrm{O}$ $0.2 \mathrm{~g}, \mathrm{H}_{3} \mathrm{BO}_{3} 0.02 \mathrm{~g}, \mathrm{CoCl}_{2} \cdot 6 \mathrm{H}_{2} \mathrm{O} 0.92 \mathrm{~g}$, $\mathrm{ZnCl}_{2} 20.0 \mathrm{~g}$ and $\mathrm{FeSO}_{4} \cdot 7 \mathrm{H}_{2} \mathrm{O} 65.0 \mathrm{~g}$.

\section{Cultivation Conditions}

All the cultivations were carried out in a 21 bioreactor (BIOSTAT, B. Braun Biotech International, Melsungen, Germany) under the following conditions: working volume $1.5 \mathrm{l}$, aeration manually adjusted to $\mathrm{pO}_{2}>$ $20 \%$, agitation max. $800 \mathrm{rpm}, \mathrm{pH}$ automatically adjusted to 6.0 by addition of $\mathrm{H}_{3} \mathrm{PO}_{4}$ aq. $8.5 \%$ or $\mathrm{NH}_{3}$ aq. $25 \%$, temperature $30{ }^{\circ} \mathrm{C}$. As an antifoam agent polypropylene glycol, PPG P2'000 was added if necessary. The process was monitored and controlled with the control unit micro-DCU-300 (B. Braun Biotech International, Melsungen, Germany). In the continuous cultivations the medium was fed with a programmable peristaltic pump (Watson Marlow 505S, Watson Marlow Limited, UK).

\section{Analytics and Instrumentation}

Concentrations of glycerol and methanol were measured by HPLC under the following conditions: column - WATREX Polymer IEX $\mathrm{H}$ form $250 \times 8 \mathrm{~mm}$ stainless steel column (Watrex Prague, Czech Republic), pump - LCP 4000.11 (ECOM s.r.o., Prague, Czech Republic), detector differential refractometer RIDK 101 (Laboratorní přístroje Praha, Prague, Czech Republic), software - Clarity ${ }^{\mathrm{TM}}$, Version 2.0 (Laboratory Imaging s.r.o., Prague, Czech Republic), flow speed $0.9 \mathrm{ml} / \mathrm{min}$, column temperature $80{ }^{\circ} \mathrm{C}$, mobile phase $5 \mathrm{mM}$ $\mathrm{H}_{2} \mathrm{SO}_{4}$.

The biomass concentration was determined as CDW.

Microscopic analyses were carried out using the phase-difference and fluorescence microscope (ECLIPSE E400, Nikon, Japan) with an ultra high pressure mercury arc lamp. The image of the cells was analysed with the LUCIA software 4.61 (LIM, Czech Republic).

Flow cytometric analyses were carried out with the PAS III instrument (PARTEC $\mathrm{GmbH}$, Münster, Germany) with a $100 \mathrm{~mW}$ mercury arc lamp and an argon ion laser (3 W) which is tuned to $488 \mathrm{~nm}$ at a power output of about $20 \mathrm{~mW}$. The fluorescence emission was collected using the following filters: FL1 = 512-545 nm; FL2 = 575-610 $\mathrm{nm}$; FL3 >630 nm. Data management and analysis were carried out using software FlowMax version 2.4 (Partec, Germany).

\section{Staining Protocols}

For the determination of the viability and vitality of the cell culture the fluorochromic dyes propidium iodide and bis(1,3-dibutylbarburic acid) trimethine oxonol $\left(\mathrm{DiBAC}_{4}(3)^{-}\right)$were chosen, and the staining methods were derived from Deere et al. [24] and optimised for the yeast Pichia pastoris. The following optimised conditions were then used during the experiment: samples were incubated with $57 \mu \mathrm{g} / \mathrm{ml}$ of PI for $5 \mathrm{~min}$ for the determination of viability and with $2 \mu \mathrm{g} / \mathrm{ml}$ of BOX for $20 \mathrm{~min}$ for the determination of the membrane potential.

\section{Results and Discussion}

The physiological response of recombinant Pichia pastoris yeast strain GS115/ lacZ/Mut+/His+ growing in continuous steady state culture to a stress situation induced by a change of carbon source from glycerol to methanol was investigated in this study. The physiological state of the cell culture was analysed with flow cytometry. For fluorescent labelling of cells two fluorescence dyes, propidium iodide (PI) targeting the membrane integrity and bis(1,3-dibutylbarburic acid) trimethine oxonol ( $\left.\mathrm{DiBAC}_{4}(3)^{-}\right)$targeting the membrane potential, were chosen.

Propidium iodide is not able to penetrate intact membranes of microorganisms but it can freely enter the cells with damaged or interrupted cytoplasmic membranes. It is selective for DNA and RNA, and the binding occurs through the intercalation of the dye into double-stranded helical structures. The percentage of viable cells was calculated as a percentage of non-stained particles after the incubation of samples with propidium iodide.

For the determination of changes of the membrane potential in the individual cell one of the most commonly used oxonol dyes, bis(1,3-dibutylbarburic acid) trimethine oxonol $\left(\mathrm{DiBAC}_{4}(3)^{-}\right.$, often referred to as bisoxonol) was used in this study. Lipophilic anionic dyes such as the oxonols can detect relatively large changes in the membrane potential and identify the heterogeneity of the response in subpopulations.

At the beginning of our work the staining methods were adapted for Pichia pastoris yeast conditions. The following staining conditions were found as optimum: PI - the concentration of the dye in the sample was $57 \mu \mathrm{g} / \mathrm{ml}$ and the time of incubation with the dye was $5 \mathrm{~min}, \operatorname{DiBAC}_{4}(3)^{-}-$the 

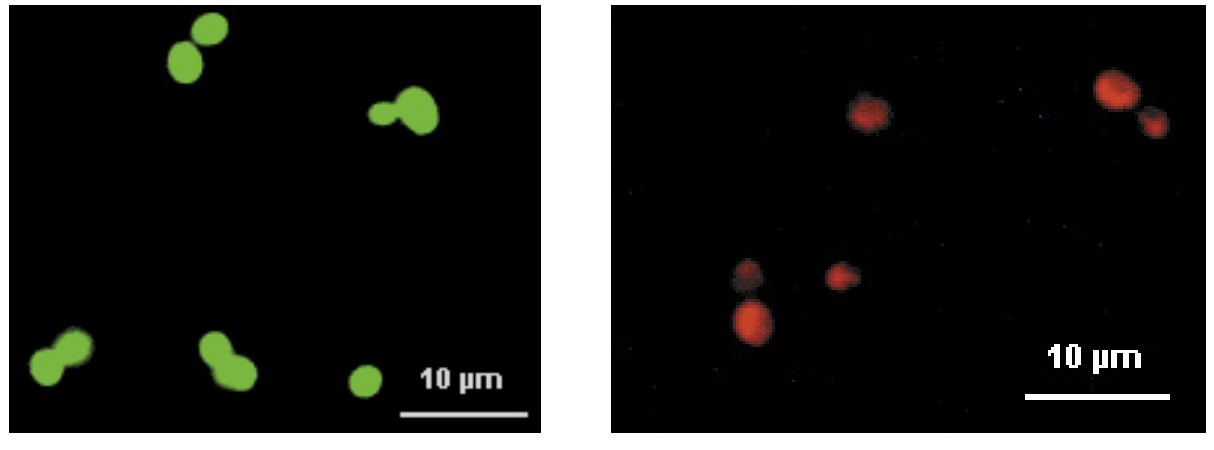

Fig. 1. The cells stained with $\operatorname{DiBAC}_{4}(3)^{-}$(left) and PI (right) observed using the fluorescence microscope

concentration of the dye in the sample was $2 \mu \mathrm{g} / \mathrm{ml}$ and the time of incubation was 20 min. The stained samples were checked using the fluorescence microscope. In Fig. 1 the cells stained with $\operatorname{DiBAC}_{4}(3)^{-}$and PI are shown.

To be sure that the chosen dyes reflected the membrane integrity and membrane potential, respectively, a number of positively stained controls were performed. The cells were incubated in the presence of $40 \mu \mathrm{g} / \mathrm{ml}$ carbonyl cyanine $m$-chlorophenylhydrazone (CCCP) that is known to collapse the membrane potential or were treated with a $70 \%$ ethanol solution for $20 \mathrm{~min}$ to affect the membrane integrity of the cells before the staining. In Fig. 2 the results of the positive staining control are shown.

Untreated exponentially grown cells (Fig. 2A, B) are stained neither with Di$\mathrm{BAC}_{4}(3)^{-}$, nor with PI, as expected.

Cells treated with CCCP are depolarised and are therefore stained with $\operatorname{DiBAC}_{4}(3)^{-}$, but not with PI (Fig. 2C, D) because the cytoplasmic membrane is compromised in function but is still structurally intact. Cells treated with ethanol solution are stained with both $\operatorname{DiBAC}_{4}(3)^{-}$and PI (Fig. 2E, F). Therefore, the PI negative cell population represents those cells with an intact membrane and generally regarded as viable cells, while PI positive cells represent dead cells. $\mathrm{DiBAC}_{4}(3)^{-}$is a lipophilic non-toxic anionic fluorescent dye that binds to the cytoplasmic membrane, provided that it is depolarised. Staining with $\mathrm{DiBAC}_{4}(3)^{-}$can also give a measure of the level of metabolic stress that cells are subjected to. Stressed, injured or otherwise, so-called viable but nonculturable cells can remain undetected by growth based methods. The results of positively stained controls were used for comparison with the results obtained during the cultivation process.

In Fig. 3 a typical trend of the cultivation process is shown. The cultivation was started up as a batch. After a batch culture period, a feeding of the medium containing $20 \mathrm{~g} / \mathrm{l}$ of glycerol at a $0.11 \mathrm{1} / \mathrm{h}$ dilution rate was initiated. Once the steady state was reached, the stress situation was induced by changing the carbon source from glycerol to methanol $(22 \mathrm{~g} / \mathrm{l})$ and the physiological response of the cell culture was studied.

From the data obtained by flow cytometry (Fig. 3), it is seen that at the start of the cultivation there is a higher percentage
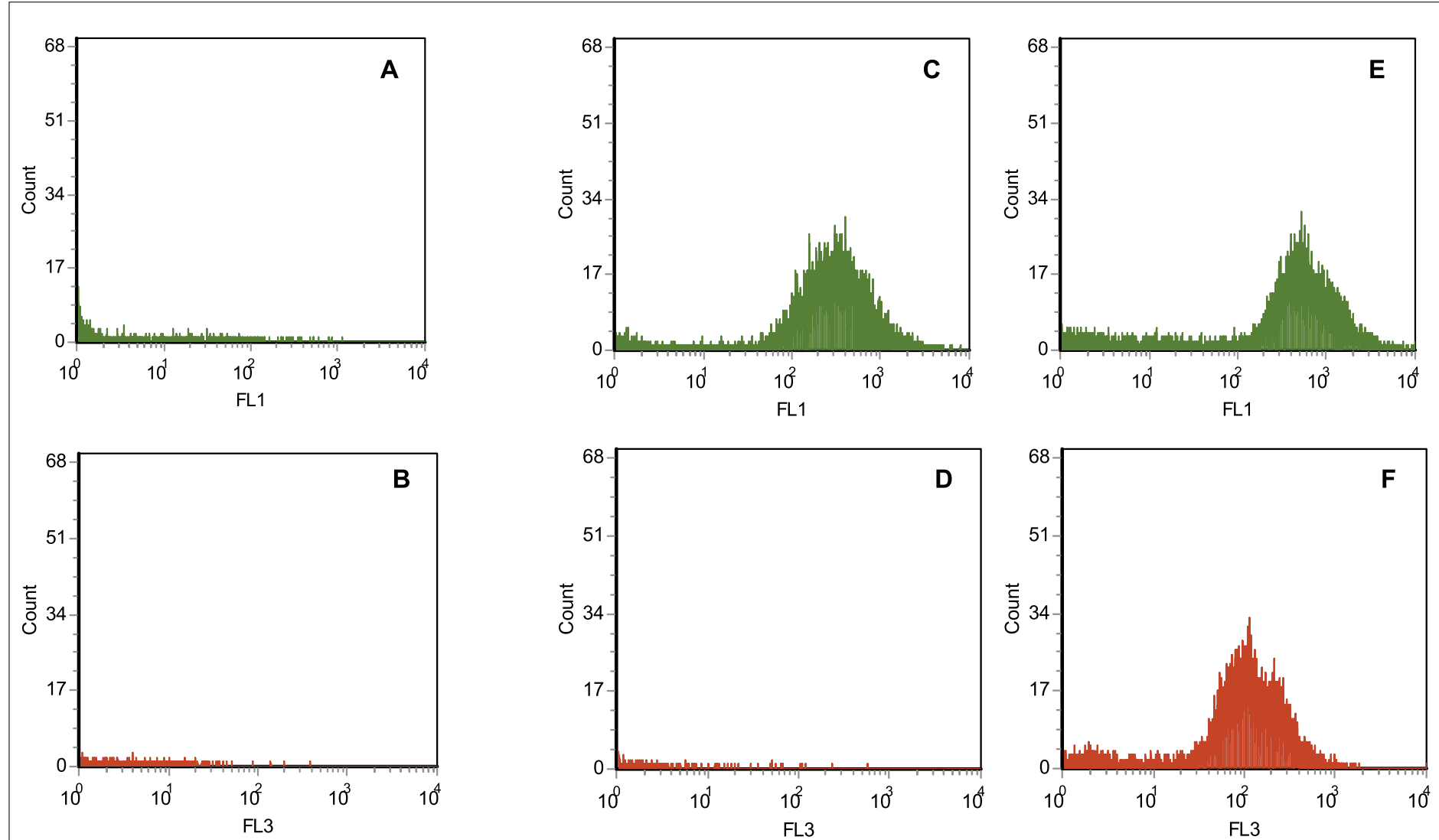

Fig. 2. The cells stained with $\operatorname{DiBAC}_{4}(3)^{-}$and $\mathrm{PI}$ analyzed with a flow cytometer. A: Untreated exponentially grown cells stained with $\mathrm{Pl}$; $\mathrm{B}$ : Untreated exponentially grown cells stained with $\mathrm{DiBAC}_{4}(3)^{-} ; \mathrm{C}$ : Cells treated with CCCP and stained with PI; $\mathrm{D}$ : Cells treated with $\mathrm{CCCP}_{\text {and stained with } \mathrm{DiBAC}}(3)^{-}$; E: Cells treated with a $70 \%$ ethanol solution and stained with PI; F: Cells treated with a $70 \%$ ethanol solution and stained with DiBAC $_{4}(3)^{-}$ 


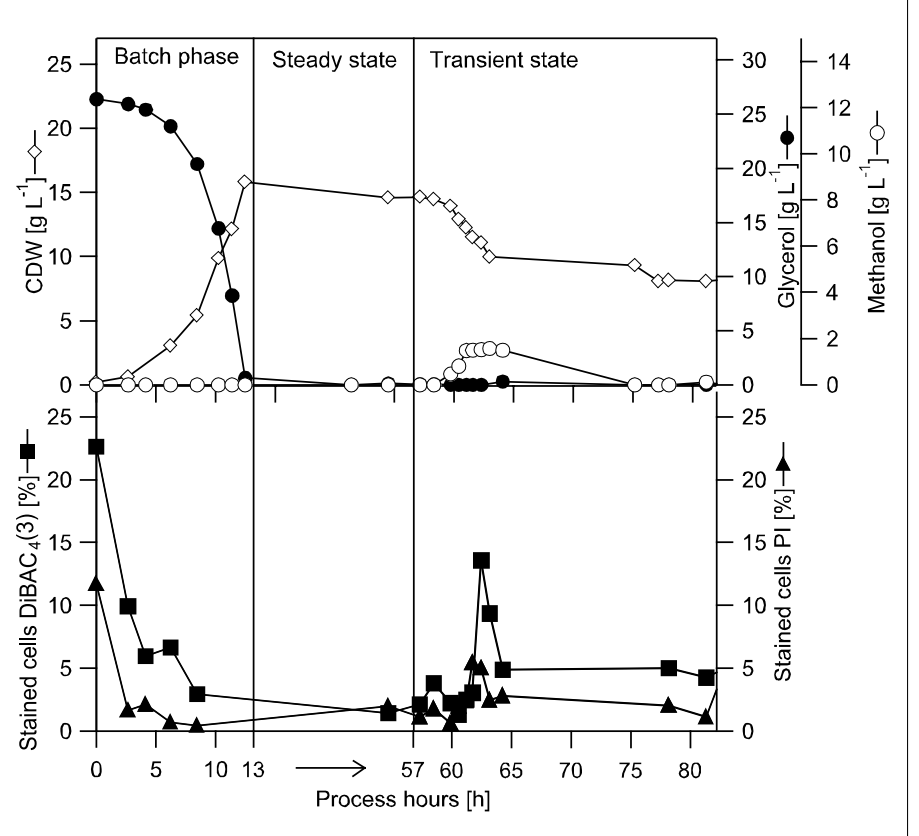

Fig. 3. A typical experiment trend. Batch phase (glycerol, $\left.\mathrm{s}_{0}=20 \mathrm{~g} / \mathrm{l}\right)$, steady state (glycerol, $\mathrm{D}=0.11 \mathrm{1} / \mathrm{h}$, $\left.\mathrm{s}_{\text {in }}=20 \mathrm{~g} / \mathrm{l}\right)$, transient state (methanol, $\mathrm{D}=0.09$ $\left.1 / \mathrm{h}, \mathrm{s}_{\text {in }}=22 \mathrm{~g} / \mathrm{l}\right)$. of both PI and $\mathrm{DiBAC}_{4}(3)^{-}$stained cells. It indicates that the cells in the inoculum were stressed due to $\mathrm{pH}$ drops, oxygen and substrate limitations of the inoculum cultivated on a shaker. During the batch cultivation on glycerol, the cells recovered due to a controlled environment in the bioreactor. During the steady state there was only approx. $1 \%$ of cells stained with PI and $2 \%$ of cells stained with $\mathrm{DiBAC}_{4}(3)^{-}$.

The stress situation was then initiated by a change of carbon source from glycerol to methanol. After methanol feeding was initiated, the decrease in the biomass concentration was accompanied with an accumulation of methanol in the culture broth. During this period the increasing percentage of dead cells stained with PI (7\%) and the stressed cells stained with $\operatorname{DiBAC}_{4}(3)^{-}(15 \%)$ indicates the stress situation caused by the toxic effect of methanol and emphasises the need for an adaptation time to the new substrate. After $5 \mathrm{~h}$ of methanol feeding, a drop in the amount of PI and $\operatorname{DiBAC}_{4}(3)^{-}$stained was detected that accompanied the decreasing concentration of methanol in the culture broth. The steady level of $2 \%$ PI and $5 \%$ DiBAC $_{4}(3)^{-}$stained cells was reached after $6 \mathrm{~h}$ of the transient state indicating the fact that the cells were adapted to a new substrate. The entire excess of methanol was consumed after $12 \mathrm{~h}$ of the transient state.

\section{Conclusions}

Flow cytometry is a useful method that is able to determine quickly the features of the cell culture not routinely measured. In our study a physiological response of Pichia pastoris yeast cells growing in steady state continuous culture to a change of substrate was determined using flow cytometry. It was proved that physiological attributes of the yeast cells, such as the membrane integrity indicating the cell viability and changes in the membrane potential providing information about the vitality of the cell culture, can be quantified with quite simple staining procedures in a relatively short time after sampling. The application of the fluorescent staining methods showed the possibility of identifying different subpopulations with different functional characteristics in the cell culture growing in the bioreactor. Such information is an important indicator for the physiological state of the cell culture that cannot be easily achieved with other methods and could serve as a basis of information for the development of new control algorithms used for the optimisation of biotechnological processes and the process control at the individual cell level.

Received: July 25, 2005

[1] H.M. Davey, D.B. Kell, Microbiol. Rev 1996, 60, 641-696.

[2] A. Patkar, N. Vijayasankaran, D.W. Urry, F. Srienc, J. Biotechnol. 2002, 93, 217229.

[3] C.K. Schuster, Adv. Biochem. Eng./Biotechnol. 1999, 66, 185-208.

[4] F. Srienc, J. Biotechnol. 1999, 71, 233238.

[5] A. Lentini, Fermentation 1993, 6, 321-327.

[6] C.J. Hewitt, G. Nebe-von-Caron, Cytometry 2001, 44, 179-187.

[7] A. Amanullah, C.J. Hewitt, A.W. Nienow, C. Lee, M. Chartrain, B.C. Buckland, S.W. Drew, J.M. Woodley, Biotechnol. Bioeng. 2002, 80, 239-249.
[8] B.S. Ferreira, C.R.C. Calado, F. van Keulen, L.P. Fonseca, J.M.S. Cabral, M.M.R da Fonseca, Appl. Microbiol. Biotechnol. 2003, 61, 69-76.

[9] J.C. Diaz-Ricci, J. Bode, J.I. Rhee, K. Schugerl, J. Bacteriol. 1995, 177, 66846687.

[10] N.S. Outchkourov, W.J. Stiekema, A. Jongsma Maarten, Protein Expr. Purif. 2002, 24, 18-24.

[11] J.J. Clare, M.A. Romanos, F.B. Rayment, J.E. Rowedder, M.A. Smith, M.M. Payne, K. Sreekrishna, C.A. Henwood, Gene 1991, 105, 205-212.

[12] J. Delgado, J.C. Liao, Biochem. J. 1992, 285, 965-72.

[13] D.R. Cavener, S.C. Ray, Nucleic Acids Res. 1991, 19, 3185-3192.

[14] L. Briand, V. Perez, J.C. Huet, E. Danty, C. Masson, J.C. Pernollet, Protein Expr. Purif. 1999, 15, 362-369.

[15] N. Koganesawa, T. Aizawa, K. Masaki, A. Matsuura, T. Nimori, H. Bando, K. Kawano, K. Nitta, Protein Eng. 2001, 14 , 705-710.

[16] L.R. Kowalski, K. Kondo, M. Inouye, Mol. Microbiol. 1995, 15, 341-353.

[17] D. Rossini, D. Porro, L. Brambilla, M. Venturini, B.M. Ranzi, M. Vanoni, L. Alberghina. Yeast 1993, 9, 77-84.

[18] J.L. Cereghino, J.M. Cregg, FEMS Microbiol. Rev. 2000, 2, 45-66.

[19] H. Hohenblum, B. Gasser, M. Maurer, N. Borth, D. Mattanovich, Biotechnol. Bioeng. 2004, 85, 367-375.

[20] G. Stephanopoulos, D. Hwang, W.A. Schmitt, J. Misra, Bioinformatics 2002 , 18, 1054-1063.

[21] S. Jin, K. Ye, K. Shimizu, J. Biotechnol. 1997, 54, 161-174.

[22] Invitrogen, 'Easy select ${ }^{\mathrm{TM}}$ Pichia Expression Kit. A manual of methods for expression of recombinant proteins using pPICZ and pPICZ $\alpha$ in Pichia pastoris' Catalog No. K1740-01, Version G 122701, 250172, 2001.

[23] S. Hellwig, F. Emde, N.P.G. Raven, M. Henke, P. Logt, R. Fischer, Biotechnol. Bioeng. 2001, 74, 344-352.

[24] D. Deere, J. Shen, G. Vesey, P. Bell, P. Bissinger, D. Veal, Yeast 1998, 14, 147-160. 